University of Nebraska - Lincoln

DigitalCommons@University of Nebraska - Lincoln

U.S. Environmental Protection Agency Papers

U.S. Environmental Protection Agency

2012

Point sources of emerging contaminants along the Colorado River Basin: Source water for the arid Southwestern United States

Tammy L. Jones-Lepp

US Environmental Protection Agency, jones-lepp.tammy@epa.gov

Charles Sanchez

University of Arizona

David A. Alvarez

U.S. Geological Survey

Doyle C. Wilson

Public Works Department, Lake Havasu City

Randi-Laurant Taniguchi-Fu

US Environmental Protection Agency

Follow this and additional works at: https://digitalcommons.unl.edu/usepapapers

Jones-Lepp, Tammy L.; Sanchez, Charles; Alvarez, David A.; Wilson, Doyle C.; and Taniguchi-Fu, RandiLaurant, "Point sources of emerging contaminants along the Colorado River Basin: Source water for the arid Southwestern United States" (2012). U.S. Environmental Protection Agency Papers. 103.

https://digitalcommons.unl.edu/usepapapers/103

This Article is brought to you for free and open access by the U.S. Environmental Protection Agency at DigitalCommons@University of Nebraska - Lincoln. It has been accepted for inclusion in U.S. Environmental Protection Agency Papers by an authorized administrator of DigitalCommons@University of Nebraska - Lincoln. 


\title{
Point sources of emerging contaminants along the Colorado River Basin: Source water for the arid Southwestern United States
}

\author{
Tammy L. Jones-Lepp a,*, Charles Sanchez ${ }^{\text {b }}$, David A. Alvarez ${ }^{\text {, }}$, \\ Doyle C. Wilson ${ }^{\mathrm{d}}$, Randi-Laurant Taniguchi-Fu ${ }^{\mathrm{e}}$ \\ a US Environmental Protection Agency, National Exposure Research Laboratory, Office of Research and Development, P.O. Box 93478, Las Vegas, NV 89193, USA \\ b University of Arizona, Department of Soil, Water, and Environmental Sciences, Yuma Agricultural Center, Yuma, AZ, USA \\ c US Geological Survey, Columbia Environmental Research Center, 4200 E. New Haven Road, Columbia, MO 65201, USA \\ ' Public Works Department, Lake Havasu City, AZ, USA \\ e Former Student Services Contractor, US Environmental Protection Agency, National Exposure Research Laboratory, Office of Research and Development \\ P.O. Box 93478, Las Vegas, NV 89193, USA
}

\section{A R T I C L E I N F O}

\section{Article history:}

Received 28 February 2012

Received in revised form 20 April 2012

Accepted 21 April 2012

Available online 8 June 2012

\section{Keywords:}

Emerging contaminants

Estrogenicity

Temporal variation

Colorado River Basin

Log $D_{\text {ow }}$

\begin{abstract}
A B S T R A C T
Emerging contaminants (ECs) (e.g., pharmaceuticals, illicit drugs, personal care products) have been detected in waters across the United States. The objective of this study was to evaluate point sources of ECs along the Colorado River, from the headwaters in Colorado to the Gulf of California. At selected locations in the Colorado River Basin (sites in Colorado, Utah, Nevada, Arizona, and California), waste stream tributaries and receiving surface waters were sampled using either grab sampling or polar organic chemical integrative samplers (POCIS). The grab samples were extracted using solid-phase cartridge extraction (SPE), and the POCIS sorbents were transferred into empty SPEs and eluted with methanol. All extracts were prepared for, and analyzed by, liquid chromatographyelectrospray-ion trap mass spectrometry (LC-ESI-ITMS). Log $D_{\text {Ow }}$ values were calculated for all ECs in the study and compared to the empirical data collected. POCIS extracts were screened for the presence of estrogenic chemicals using the yeast estrogen screen (YES) assay. Extracts from the 2008 POCIS deployment in the Las Vegas Wash showed the second highest estrogenicity response. In the grab samples, azithromycin (an antibiotic) was detected in all but one urban waste stream, with concentrations ranging from $30 \mathrm{ng} / \mathrm{L}$ to $2800 \mathrm{ng} / \mathrm{L}$. Concentration levels of azithromycin, methamphetamine and pseudoephedrine showed temporal variation from the Tucson WWTP. Those ECs that were detected in the main surface water channels (those that are diverted for urban use and irrigation along the Colorado River) were in the region of the limit-of-detection (e.g., $10 \mathrm{ng} / \mathrm{L}$ ), but most were below detection limits.
\end{abstract}

Published by Elsevier B.V.

\section{Introduction}

Located in the western half of the United States (US) is the Colorado River, which is a major source of water (e.g., drinking, agricultural, industrial) for millions of people living in the southwestern part of the United States (e.g., Arizona, Southern California, Colorado, Nevada, and Utah) and Baja California, Mexico. The focus of this paper was to identify and characterize point sources of a select subset of emerging contaminants (ECs) (e.g., pharmaceuticals, illicit drugs) entering the Colorado River so that this information can be used by water management authorities in their decision making regarding the use, and reuse, of source waters. Samples were collected throughout the Colorado River Basin (CRB), starting in the Upper Basin at Grand Lake, Colorado (the headwaters of the Colorado River), down the Lower Basin, and concluding at the Northern International Boundary (NIB) between California and Mexico (Fig. 1).

\footnotetext{
* Corresponding author at: US Environmental Protection Agency, 944 E. Harmon Ave., Las Vegas, NV 89119, USA. Tel.: +1 702798 2144; fax: +1 7027982142.

E-mail address: jones-lepp.tammy@epa.gov (T.L. Jones-Lepp).
}

Nine ECs were chosen for screening, including four antibiotics: three macrolides (azithromycin, clarithromycin, roxithromycin), one lincosamide (clindamycin); one narcotic (hydrocodone); one over-the-counter (OTC) (pseudoephedrine); two illicit drugs (methamphetamine, MDMA or Ecstasy); and one marker of untreated human waste (urobilin). These nine were specifically chosen because of their polar characteristics, amenability to the methodologies used, socially-related reasons, and for their potential for adverse human and aquatic affects. As an example, the four antibiotics were chosen for study because of (1) their widespread use in the US [i.e., azithromycin is the top macrolide antibiotic prescribed in the US, with nearly 49 million prescriptions in 2010 (DrugTopics.com, 2010)], and (2) concern that the presence of antibiotics in wastewater effluents, along with the presence of antibiotic resistant genes (ARg) and antibiotic resistant bacteria (ARb) are creating environmental "hot spots" (Castiglioni et al., 2008; Kemper, 2008; Kim and Aga, 2007; Le-Minh et al., 2010; Loganathan et al., 2009; Merlin et al., 2011; Munir et al., 2011; Rosenblatt-Farrell, 2009; Schwartz et al., 2003; Segura et al., 2009; Seveno et al., 2002). Uncertainty exists as to what will develop from these hot spots, and it has been suggested that more wide-spread 


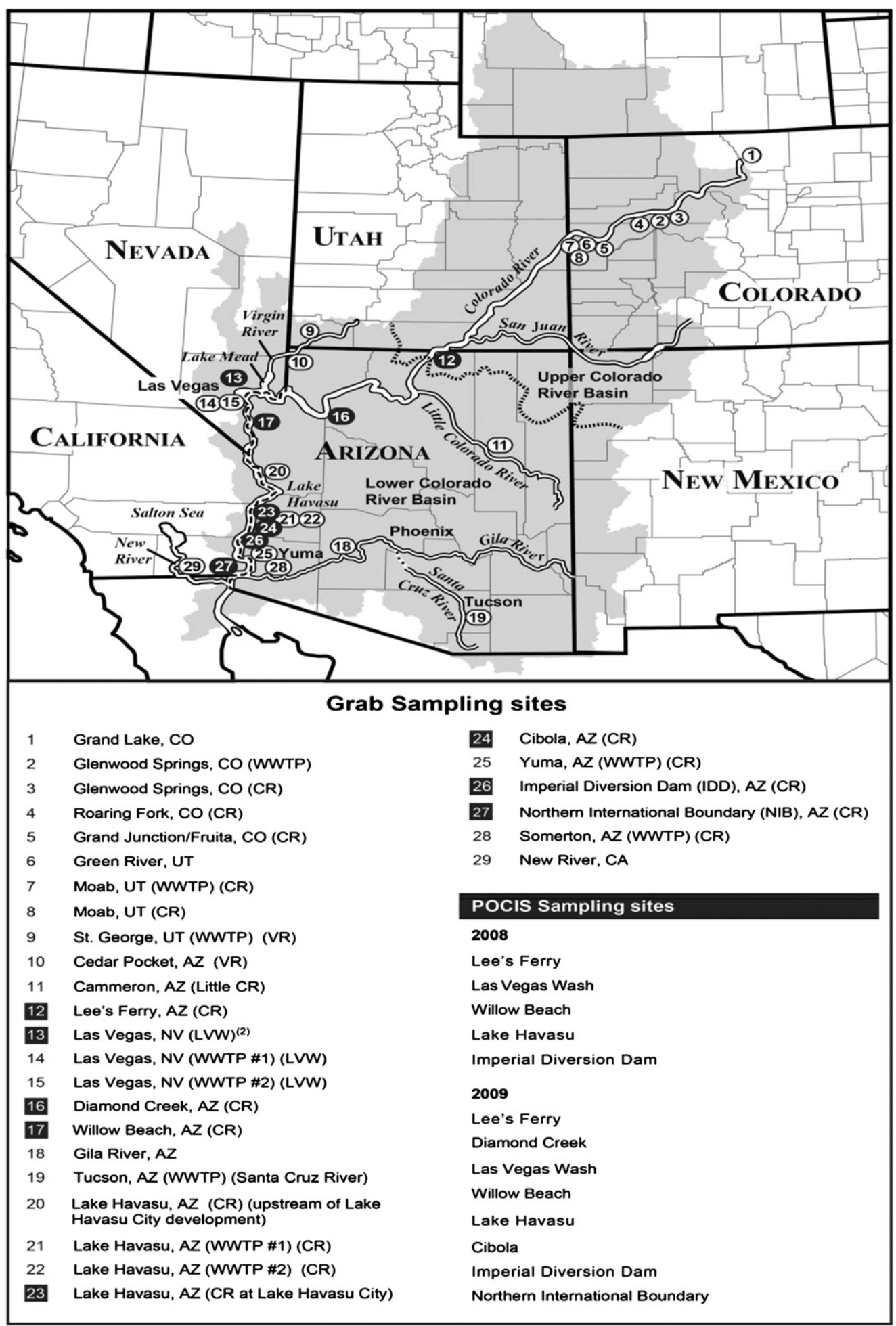

Fig. 1. Colorado River Basin Watershed.

and global ARb will arise from these hot spots (Seveno et al., 2002); thereby, rendering modern antibiotics useless or weakened in potency (Felmingham et al., 2007; Knapp et al., 2010). The two illicit drugs (methamphetamine and MDMA) were chosen because of their reported abuse and limited environmental occurrence data in the US (Banta-Green et al., 2009; Bartelt-Hunt et al., 2009; Boles and Wells, 2010; Chiaia et al., 2008; Jones-Lepp et al., 2004; Loganathan et al., 2009). Urobilin, a chemical marker of untreated human waste, was selected because it can be helpful in determining the presence of raw human waste (Jones-Lepp,
2006; Loganathan et al., 2009). The nine emerging contaminants of this study and their chemical formula, CAS \#, molecular weight, and log $D_{\text {ow }}$ are shown in Supplemental Table 1.

The potential for adverse effects from ECs on human health is unknown, but is becoming a concern due to the increasing multi-use and reuse character of wastewater effluent (e.g., snowmaking, golf course irrigation, landscape irrigation, crop irrigation, etc.), and especially where in some cases it is continuously recycled in a closed-loop. This multi-use and recycling of wastewater effluent and the impact 
upon Southwestern water resources (e.g., Colorado River, Santa Cruz River, Gila River, etc.) increase the potential for cumulative increases of ECs into water supply sources. In the near future, water reuse will become especially important in densely populated arid areas where there is an increasing demand to supply water from limited supplies. Human well-being in a future world will depend more heavily upon this sustainable resource and the characterization of ECs will become important for ecological and human health risk assessments and commodity valuation of water resources (Blasco and Pico, 2009; Young, 2005).

\section{Experimental}

\subsection{Chemicals}

Clarithromycin was obtained from US Pharmacopeia (Rockville, MD, USA). Azithromycin, roxithromycin, and clindamycin were obtained from Sigma-Aldrich (St. Louis, MO) or United States Pharmacopeia (USP, Rockville, MD). Methamphetamine, MDMA, $\mathrm{d}_{5}$-MDMA, hydrocodone, and pseudoephedrine were obtained from Cerilliant Corporation (Round Rock, TX). Urobilin was obtained from Frontier Scientific (Logan, UT). HPLC-grade methanol was obtained from varying sources [e.g., Burdick and Jackson (Muskegon, MI); EK Industries (Joliet, IL); JT Baker (Phillipsburg, NJ)]. ACS reagent grade acetic acid, glacial and HPLC-grade methyl tert butyl ether (MTBE) were obtained from VWR (West Chester, PA). Acetonitrile was obtained from Burdick and Jackson (Muskegon, MI). Formic acid, ACS reagent grade, was obtained from Anachemia (Rouses Point, NY). Deionized water was produced on-site using a NANOpure ${ }^{\mathrm{TM}}$ filtration system (Barnstead, Dubuque, Iowa, USA).

Stock standard solutions were individually prepared from pure standards diluted with HPLC-grade methanol and stored in darkness at $<4{ }^{\circ} \mathrm{C}$. A high-level standard mix, used for spiking and calibration standards, was prepared bimonthly in methanol, at concentrations of 10 or $20 \mathrm{ng} / \mu \mathrm{L}$. Mass spectrometric calibration standards were prepared weekly, from the high-level standard mix, ranging from 0.25 to $2 \mathrm{ng} / \mathrm{\mu L}$ in $99 \%$ methanol:1\% acetic acid.

\subsection{Sampling sites}

Sampling sites were chosen from the Upper and Lower Colorado River Basin. Grab water samples, combined with the deployment of passive samplers (polar organic chemical integrative samplers, POCIS), were collected starting at the headwaters of the Colorado River (located on the western slopes of the Rocky Mountains), continuing down the Colorado River, until reaching the NIB at Mexico (Fig. 1). Samples also were collected from tributaries (i.e., Green River, Virgin River, Gila River, Santa Cruz River, and the Las Vegas Wash) that reside within the Upper and Lower Basin watershed. While these sites are not along the Colorado River, they do eventually flow into the Colorado River and are part of the CRB watershed. Several of these streams, like the Santa Cruz and Gila River, are mostly ephemeral streams, with their flows resulting from monsoonal storms, winter rains, agricultural runoff, and wastewater treatment plant (WWTP) effluent.

\subsection{Sample collection: grab and passive sampling techniques}

Water samples were collected using either grab sampling or the passive sampling technique, POCIS. Passive samplers were deployed for approximately 30 days at certain collection sites, and collected in conjunction with the grab sampling collection dates for comparison purposes to the grab sampling.

\subsubsection{Grab sampling}

A pre-cleaned (i.e., acid washed, rinsed with methanol and deionized water, and baked at $105^{\circ} \mathrm{C}$ until dry) 4-L amber glass bottle was submerged under water until filled. The grab samples were placed in a cooler, on ice, transported overnight to the laboratory, and stored at
$<4{ }^{\circ} \mathrm{C}$ until extraction. Extractions usually occurred on the date of receipt of the samples, and were analyzed by liquid chromatographymass spectrometry/mass spectrometry (LC-MS/MS), as described in Section 2.5.

\subsubsection{Passive sampling}

Passive sampling devices were used to obtain time-weighted average (TWA) concentration of dissolved organic contaminants at select sites. The POCIS was chosen for this study as it is designed to sample organic chemicals ranging from hydrophilic to moderately hydrophobic (Alvarez et al., 2004). ECs, such as the pharmaceuticals and illicit drugs targeted in this study, pass through the semipermeable membrane of the POCIS and are trapped onto a solidphase sorbent. The sequestered chemicals are then recovered from the sorbent in the laboratory using a simple organic solvent extraction (Alvarez et al., 2008). Briefly, the POCISs were gently cleaned, and the sorbents from each POCIS were transferred into empty SPE cartridges ( $25 \mathrm{~mL}$ capacity) for extraction. Chemical residues were recovered from the POCIS sorbent using $40 \mathrm{~mL}$ of methanol. The samplers were deployed for approximately 30 days at select study sites, corresponding to grab sample sites (except for Cibola, where only POCIS was deployed): Lee's Ferry (AZ); Diamond Creek (AZ); Las Vegas Wash (NV); Willow Beach (AZ); Lake Havasu (AZ); Cibola $(\mathrm{AZ})$; Imperial Diversion Dam (AZ); and Northern International Boundary (AZ/CA/Mexico).

The United States Environmental Protection Agency-Las Vegas (USEPA-Las Vegas), using the LC-MS/MS technique described in Section 2.5, analyzed the POCIS extracts for ECs. The POCIS extracts were also screened for estrogenic activity using the yeast estrogen assay (YES) screen, described in Section 2.7.

\subsection{Grab sample preparation and solid-phase extraction}

Briefly, water samples were acidified and placed onto an AutoTrace $^{\mathrm{TM}}$ solid-phase extraction (SPE) workstation (Dionex Corp, Sunnyvale, CA). The extractions were performed using Oasis MCX SPE (6 cc, $150 \mathrm{mg}$ ) cartridges (Waters Corp., Milford, MA). The eluants were reduced in volume to 0.5 and solvent exchanged with methanol/1\% acetic acid, transferred to 2-mL clear glass vials and stored in a refrigerator, at $<4{ }^{\circ} \mathrm{C}$ until analysis by LC-MS/MS. More details can be found in the Supplementary file.

\section{5. $L C-M S / M S$ analysis}

A Varian 500MS (Walnut Creek, CA) ion trap mass spectrometer, configured with an electrospray ion source, and a Varian 212-liquid chromatograph, was used for all analyses. Mid-range calibration standards $(0.5$ and $1 \mathrm{ng} / \mu \mathrm{L})$ were analyzed at the beginning and end of each analytical day. A volume of $5 \mu \mathrm{L}$ was injected for each standard. Linearity and precision of the daily calibration standards were measured from an initial 3-pt calibration curve prepared and analyzed weekly. A volume of $10 \mu \mathrm{L}$ was injected for each sample extract. More detailed LC-MS/MS conditions can be found in the Supplemental section.

Due to potentially interfering materials co-extracted with the ECs, the analyses were performed using the collision induced dissociation (CID) mode for both identification and for calculation of the concentration of the analytes of interest. Two to three product ions were used for identification and the most abundant product ion was chosen for quantification. The precursor ion and most abundant product ion that were used to identify and quantify the nine ECs, and their limits-of-detection (LOD, on-column) are listed in Supplemental Table 2. 


\subsection{Quality control}

Trip blanks; spike recoveries of each EC in DI water, river water and wastewater matrices (Supplemental Table 3); and precision and accuracy of calibration standards and sample spikes were determined over the course of the study.

For the POCIS, a combination of field blanks and laboratory blanks was used for both the LC-MS/MS analyses and the estrogenic assays. Field blanks were opened to the ambient air during the deployment and retrieval of the passive samplers. Although the chemicals targeted in this study are not likely to be present in the air, field blanks are important, as other interfering chemicals may have been sampled during these operations.

\subsection{Estrogenic assays}

POCIS extracts were screened for estrogenicity using the YES assay (Alvarez et al., 2008), which uses recombinant yeast cells that are transfected with the human estrogen receptor. The recombinant yeast cells also contain expression plasmids carrying a reporter gene (lac- $z$ ) situated downstream from a promoter sequence, which incorporates an estrogen response element (ERE). Following the binding of a suitable agonist, the yeast cells undergo a cascade of events that result in the release of $\beta$-galactosidase into the growth media. The $\beta$ galactosidase interacts with a chromogenic substrate (chlorophenol red- $\beta$-D-galactopyranoside - CPRG) in the media subsequently producing a color change that can be measured spectrophotometrically. The strength of the color change is a measure of the estrogenic potential of chemicals in the sample. The 96-well test plates were prepared by adding a positive control ( $17 \beta$-estradiol) in the first row and alternating negative controls ( $200 \mu \mathrm{L}$ ethanol) and test samples ( $50 \mu \mathrm{L}$ extract diluted with $150 \mu \mathrm{L}$ ethanol in triplicate) in the following rows. All samples and controls are then serially diluted across the test plate. The liquid in each well was allowed to evaporate prior to adding $200 \mu \mathrm{L}$ of assay medium containing $\approx 4 \times 10^{7}$ recombinant yeast cells and CPRG. The plates were gently agitated, sealed, and incubated at $30{ }^{\circ} \mathrm{C}$ for up to $72 \mathrm{~h}$. Each day, the plates were inspected for the conversion of CPRG in the positive controls to determine the speed of plate development. After $72 \mathrm{~h}$, the color change was monitored using a plate reader and the absorbance was measured at 540 and $620 \mathrm{~nm}$.

\section{Results and discussion}

\subsection{Occurrence of emerging contaminants in the Colorado River Basin}

Of the antibiotics, only azithromycin, with concentrations ranging from $30 \mathrm{ng} / \mathrm{L}$ to $2800 \mathrm{ng} / \mathrm{L}$, was routinely detected in all grab samples of wastewater effluents (with the exception of Moab, UT) that enter into the Colorado River or its tributaries (Table 1). The other three antibiotics, i.e., roxithromycin, clarithromycin, and clindamycin, were infrequently detected at lower concentrations in the wastewater effluents. In comparison to other studies done in the US, the azithromycin concentrations in this study are similar to those found by BarteltHunt et al. (2009) in US WWTP effluents from small and large WWTPs in Nebraska (Bartelt-Hunt et al., 2009). The concentrations they detected ranged from non-detect to over $1500 \mathrm{ng} / \mathrm{L}$, in the effluent from a large WWTP in Lincoln, Nebraska, population $>250,000$ (Bartelt-Hunt et al., 2009). Murata et al. (2011) reported similar concentrations of azithromycin in Japan, while the levels of clarithromycin detected were slightly higher (Murata et al., 2011). In the Arc river, southern France, Feitosa-Felizzola and Chiron (2009) reported no findings of azithromycin, but very high levels of clarithromycin in comparison to this study (Feitosa-Felizzola and Chiron, 2009). Lin et al. (2008) report concentrations of azithromycin, in Taiwan, consistent with this study, but much higher levels of clarithromycin and clindamycin. Very low levels of azithromycin, as compared to this study, were detected in several WWTPs located in the Ebro Basin in Spain (Gros et al., 2007). However, it is difficult to compare antibiotic usage across countries, as different countries prescribe different antibiotics, for example roxithromycin is not prescribed in the US, but it is prescribed in Latin America and Europe.

Pseudoephedrine and hydrocodone were detected in several wastewater effluents, ranging in concentrations from 120 to $3300 \mathrm{ng} / \mathrm{L}$ for pseudoephedrine, and 330 to $900 \mathrm{ng} / \mathrm{L}$ for hydrocodone (Table 1). Hydrocodone was not screened as an emerging contaminant until half-way through the study time period (2007-2009); therefore, many sites do not have collection data for this compound. Postigo et al. (2008) found similar levels of ephedrine/pseudoephedrine in waste water effluents in Spain.

The illicit drugs, methamphetamine and MDMA (Ecstasy), were detected in several WWTP effluents. The concentrations of methamphetamine ranged from non-detect to $570 \mathrm{ng} / \mathrm{L}$ in WWTP effluents, while MDMA concentrations ranged from non-detect to nearly $100 \mathrm{ng} / \mathrm{L}$ (Table 1). These values are consistent with what others have reported being detected in US effluents (Bartelt-Hunt et al., 2009; Chiaia et al., 2008).

The raw human waste marker, urobilin was detected in several WWTP waste streams, as well as at the New River site (Table 1). The presence of urobilin, along with the presences of human-use drugs/metabolites, can be good indicators of raw human waste (Jones-Lepp, 2006) and identification of these indicators has been used extensively by USEPA's Region 1 to detect and document water quality violations and enforcement actions resulting in the elimination of millions of gallons per year of raw sewage from storm water outfalls (Borci, 2012). Usually, most WWTPs do not discharge urobilin if they are operating properly, and if there are no storm surge overflows. However, high storm sewer overflow can severely impact a WWTP's ability to remove urobilin; and hence, harmful bacteria.

There were five sites that were not wastewater streams where ECs were detected: Cedar Pocket (AZ), Las Vegas Wash (NV), Lake Havasu (AZ), Imperial Diversion Dam (IDD) (AZ), and New River (CA). Pseudoephedrine was detected at $290 \mathrm{ng} / \mathrm{L}$ at Cedar Pocket (AZ), this amount was approximately $70 \%$ of the amount detected upstream in the St. George WWTP effluent $(430 \mathrm{ng} / \mathrm{L})$ that was collected on the same day (Table 1). Cedar Pocket (site \#10 in Fig. 1) is located along the Virgin River and is approximately $17 \mathrm{~km}$ downstream from the St. George WWTP (site \#9, Fig. 1). At a flow rate of $8.78 \mathrm{~m}^{3} / \mathrm{s}$ (real-time data for August 5, 2008 from USGS water gage station (\# 09413700) located below both sites near Littlefield, AZ), it takes a few hours for the water to travel the $17 \mathrm{~km}$. Pseudoephedrine is a small molecule, $165 \mathrm{Da}$, and has a $\log D_{\mathrm{ow}}<1$, e.g., -1.28 at $\mathrm{pH} 7$, it can be expected that the average levels of use and excretion of pseudoephedrine were fairly consistent over a short period of time. Therefore, it stands to reason that the pseudoephedrine detected at Cedar Pocket is from the effluent from the wastewater treatment plant $17 \mathrm{~km}$ upstream. Log $D_{\text {ow }}$ and its importance to environmental occurrence data will be discussed later in Section 3.4.

Methamphetamine was detected in the Las Vegas Wash grab samples (Table 1). This site is located approximately $8 \mathrm{~km}$ downstream from the nearest WWTP effluent stream (Henderson, NV), and $15 \mathrm{~km}$ downstream from WWTP \#1 and WWTP \#2 (Las Vegas, NV). All three WWTPs sit along the Las Vegas Wash wetlands area, which ultimately feeds into the Las Vegas Wash and subsequently, Lake Mead and the Colorado River. Again, methamphetamine, like pseudoephedrine, is a small molecule, $149 \mathrm{Da}$, and has a $\log D_{\mathrm{OW}}<1$, e.g., -0.72 at $\mathrm{pH} 7$.

In Lake Havasu (AZ), both methamphetamine and MDMA were detected during the July 2007 collection event. Lake Havasu (AZ) is a popular southwest recreational site especially during the summer months. The Lake Havasu collection site was upstream from the effluent waste streams of the Lake Havasu WWTPs. MDMA was detected 
Table 1

Concentrations of emerging contaminants collected from Colorado River Basin.

\begin{tabular}{|c|c|c|c|c|c|c|c|c|c|c|}
\hline \multirow[t]{2}{*}{$\begin{array}{l}\text { Sampling } \\
\text { sites }\end{array}$} & \multirow[t]{2}{*}{ Dates sampled } & \multicolumn{9}{|l|}{$\begin{array}{l}\text { Analytes } \\
\mathrm{ng} / \mathrm{L}\end{array}$} \\
\hline & & Urobilin & Azithro. & Roxithro. & Clarithro. & Clinda. & Meth. & MDMA & Pseudoephedrine & Hydrocodone \\
\hline 1 & $07 / 20 / 08$ & - & - & - & - & - & - & - & - & - \\
\hline 2 & 07/20/08; 08/06/09 & $1400 ; 340$ & $170 ; 910$ & - & - & - & $350 ; 360$ & $96 ;-$ & $1800 ; 3300$ & NA; 910 \\
\hline 3 & $07 / 19 / 08$ & - & - & - & - & - & - & - & - & NA \\
\hline 4 & $07 / 20 / 08,08 / 06 / 09$ & - & - & - & - & - & - & - & - & NA \\
\hline 5 & $07 / 18 / 08$ & - & - & - & - & - & - & - & - & NA \\
\hline 6 & $07 / 15 / 08,08 / 07 / 09$ & - & - & - & - & - & - & - & - & $\mathrm{NA},-$ \\
\hline 7 & $07 / 16 / 08$ & - & - & - & - & - & - & - & - & NA \\
\hline 8 & 07/18/08; 08/08/09 & - & - & - & - & - & - & - & - & $\mathrm{NA} ;-$ \\
\hline 9 & $08 / 05 / 08$ & - & 150 & - & - & 950 & - & - & 430 & NA \\
\hline 10 & 08/05/08; 07/19/09 & - & - & - & - & - & - & - & $290 ;-$ & NA \\
\hline 11 & $07 / 14 / 08$ & - & - & - & - & - & - & - & - & NA \\
\hline 12 & 07/14/08, 08/08/09 & - & - & - & - & - & - & - & - & $\mathrm{NA} ;-$ \\
\hline $13^{\mathrm{b}}$ & $06 / 30 / 08 ; 07 / 19 / 09$ & - & - & - & - & - & $210 ; 250$ & - & - & $\mathrm{NA}$ \\
\hline 14 & $01 / 19 / 11^{a} ; 06 / 19 / 11^{a}$ & - & $66 ; 44$ & - & $75 ;-$ & $180 ;-$ & $310 ; 230$ & - & $340 ; 270$ & - \\
\hline 15 & $11 / 18 / 08^{a} ; 05 / 22 / 11^{a}$ & $-; 60$ & $31 ; 2800$ & - & $40 ; 130$ & $1150 ; 120$ & $370 ; 83$ & - & $3100 ;-$ & NA; 330 \\
\hline 16 & $06 / 20 / 08$ & - & - & - & - & - & - & - & - & NA \\
\hline 17 & $06 / 20 / 08$ & - & - & - & - & - & - & - & - & NA \\
\hline 18 & 02/20/08 & - & - & - & - & - & - & - & - & NA \\
\hline 19 & $02 / 18 / 08^{a}$ & - & 140 & - & - & - & 110 & - & 180 & NA \\
\hline 19 & 03/19/08 & - & 920 & - & - & - & 270 & - & 340 & NA \\
\hline 19 & 04/10/08 & - & 240 & 180 & - & - & 260 & - & 340 & NA \\
\hline 19 & $04 / 18 / 08^{a}$ & - & 1300 & - & 370 & - & 230 & - & 120 & NA \\
\hline 19 & $05 / 26 / 08^{a}$ & - & 460 & - & - & - & 470 & - & 400 & NA \\
\hline 19 & 06/07/08 & - & 160 & - & - & - & 570 & - & 1000 & NA \\
\hline 20 & $05 / 14 / 07$ & - & - & - & - & - & - & - & NA & NA \\
\hline 20 & 07/09/07 & - & - & - & - & - & $<\mathrm{LOD}^{\mathrm{c}}$ & 35 & NA & NA \\
\hline 20 & $11 / 05 / 07^{\mathrm{a}}$ & - & - & - & - & - & - & - & NA & NA \\
\hline 21 & 05/14/07 & - & 6 & - & - & - & - & 34 & NA & NA \\
\hline 21 & $11 / 07 / 07$ & - & 50 & - & - & - & - & - & NA & NA \\
\hline 21 & $02 / 25 / 08$ & - & 11 & - & 78 & - & 190 & - & - & NA \\
\hline 22 & $05 / 14 / 07^{\mathrm{a}}$ & - & 17 & - & - & - & - & 68 & - & NA \\
\hline 22 & 07/09/07 & 5 & 52 & - & - & 26 & - & $<\operatorname{LOD}^{\mathrm{C}}$ & - & NA \\
\hline 22 & $11 / 07 / 07$ & - & 40 & - & - & - & - & - & - & NA \\
\hline 22 & $02 / 25 / 08$ & - & 96 & - & - & 550 & - & - & 280 & NA \\
\hline 23 & $02 / 25 / 08$ & - & - & - & - & - & - & - & - & NA \\
\hline 25 & $06 / 06 / 08^{a} ; 07 / 21 / 09^{a}$ & - & $350 ; 770$ & - & - & $-; 740$ & $-; 570$ & - & - & $\mathrm{NA} ;-$ \\
\hline 26 & $10 / 15 / 07^{a} ; 01 / 21 / 08^{a}$ & - & - & - & - & - & - & $<\mathrm{LOQ}^{\mathrm{c}} ;<\mathrm{LOD}^{\mathrm{c}}$ & - & NA \\
\hline 26 & 02/20/08-07/21/09 & - & - & - & - & - & - & - & - & NA \\
\hline 27 & $02 / 20 / 08 ; 06 / 11 / 08$ & 31 & - & - & - & - & $-; 83$ & - & - & NA \\
\hline 28 & $06 / 08 / 08$ & - & - & - & - & - & 110 & - & - & NA \\
\hline 29 & $02 / 19 / 08^{a}$ & 32 & - & 110 & 6 & - & 200 & - & 140 & NA \\
\hline
\end{tabular}

“-" = not detected. NA = compound was not analyzed for. Azithro. = azithromycin; Roxithro. = roxithromycin; Clarithro. = clarithromycin; Meth. = methamphetamine. ${ }^{\text {a Average }}$ from duplicates. ${ }^{\mathrm{b}}$ This collection site is approximately $15 \mathrm{~km}$ downstream from the WWTP \#1 and WWTP \#2. ${ }^{\mathrm{c}}$ Analyte detected spectral confirmation, but below LOD or LOQ.

Legend for the sampling sites:

1 Grand Lake, CO

2 Glenwood Springs, CO (WWTP)

3 Glenwood Springs, CO (CR)

4 Roaring Fork, CO (CR)

5 Grand Junction/Fruita, CO (CR)

6 Green River, UT

7 Moab, UT (WWTP) (CR)

8 Moab, UT (CR)

9 St. George, UT (WWTP) (VR)

10 Cedar Pocket, AZ (VR)

11 Cammeron, AZ (Little CR)

12 Lee's Ferry, AZ (CR)

13 Las Vegas, NV (LVW)

14 Las Vegas, NV (WWTP \#1) (LVW)

15 Las Vegas, NV (WWTP \#2) (LVW)
16 Diamond Creek, AZ (CR)

17 Willow Beach, AZ (CR)

18 Gila River, AZ

19 Tucson, AZ (WWTP) (Santa Cruz River)

20 Lake Havasu, AZ (CR) (upstream of Lake Havasu City development)

21 Lake Havasu, AZ (WWTP \#1) (CR)

22 Lake Havasu, AZ (WWTP \#2) (CR)

23 Lake Havasu, AZ (CR at Lake Havasu City)

24 Cibola, AZ (CR)

25 Yuma, AZ (WWTP) (CR)

26 Imperial Diversion Dam (IDD), AZ (CR)

27 Northern International Boundary (NIB), AZ (CR)

28 Somerton, AZ (WWTP) (CR)

29 New River, CA

Sample Type: CR = Colorado River; LVW = Las Vegas Wash; VR = Virgin River; WWTP = wastewater treatment plant.

twice at very low levels ( $<$ LOQ $<$ LOD, but spectrally confirmed), out of seven sampling events, at the IDD site, which is located downstream from Lake Havasu.

Roxithromycin and clarithromycin, 110 and $6 \mathrm{ng} / \mathrm{L}$, respectively, were detected at the New River sample site, which was located just inside the US border at Calexico, California (Table 1). Roxithromycin, a macrolide antibiotic, while not prescribed in the US, is a widely prescribed antibiotic in Latin America and Europe. Also detected at the New River sample site were methamphetamine, pseudoephedrine, and urobilin (raw human waste marker). The New River is unique in that it is one of the few rivers that flow northwards into the US from Mexico. The New River starts in Mexico, flows through the city 
of Mexicali (Mexico) across the US border, through Calexico (US) and numerous agricultural fields before it empties into the Salton Sea, CA (US). There are municipal waste streams, raw waste, industrial, and agricultural wastes all entering the New River at various points along the river, both inside Mexico and in the US.

\subsection{Passive sampling (POCIS)}

In 2008 and 2009 field studies the POCISs were deployed at a few select sites: Lee's Ferry (AZ), Diamond Creek (AZ), Las Vegas Wash convergence (NV), Willow Beach (AZ), Lake Havasu (AZ), Cibola (AZ), IDD (AZ); and NIB (AZ/CA/Mexico); to examine and compare the analytes detected between POCIS and grab sampling. POCIS analytes were measured as total ng per POCIS, and then back-calculated using flow rates and uptake rates for correction to $\mathrm{ng} / \mathrm{L}$ values (Alvarez et al., 2004). ECs were detected at only three sites using the POCIS: Las Vegas Wash (NV); Willow Beach (AZ); and NIB (AZ/ CA/Mexico) (Table 2).

\subsection{Comparison of grab and passive sampling}

Grab sampling has limitations in that when a sample is taken, it is a "snapshot" of what contaminants are present at that particular moment in time. There is always the vulnerability of collecting a sample just before, or after, contaminants pass by through the water column, and leading to a false negative finding. To test this hypothesis, POCISs were deployed at select sites concurrently with the collection of grab samples. In 2008, at two of the sites, Lee's Ferry and IDD, there were no chemicals detected in either the POCIS or grab samples. At the Las Vegas Wash convergence sample site, several analytes were detected in the POCIS extracts whereas only methamphetamine was present in the grab sample. In 2009, the numbers of chemicals detected in the POCIS and grab samplers were similar. Comparing the number of analyte detections indicates that the POCIS did a better job of identifying the occurrence of these chemicals than the grab samples did. However, the estimated water concentrations were generally lower in the POCIS.

Direct comparison of the results between the two sampling techniques should not be made without first understanding the differences in the information provided by both techniques. Grab samples provide a snapshot of the concentration in the water at that exact location and time. Passive techniques provide an integrated view of the concentration of analytes in the water over the entire deployment period. In a flowing body of water, the passive techniques may also provide a slightly better view of the overall chemical concentration in a small area as mixing over time will occur. Often the results will be similar, but they should not be expected to be so. It is well documented that areas directly impacted by WWTPs experience temporal changes in chemical concentrations (often throughout a single day) due to changes in human activities (Gerrity et al., 2011; Managaki et al., 2008; Ort et al., 2005). Also of note is that most of the grab samples were collected over weekend periods where there would be an expected greater influx of human activities in popular vacation areas (such as Las Vegas). It is reasonable to assume that concentrations of certain chemicals would be increased compared to the rest of the work week along with the increase in people visiting an area.

\subsection{Environmental persistence as linked to $\log D_{\mathrm{OW}}$}

The release and persistence of ECs into aquatic ecosystems depend upon their physical-chemical properties and the chemical properties and biological characteristics of the water compartment. These include concentration of dissolved/suspended organic matter, solubility, microbial population, physical (e.g., volatilization from and adsorption to suspended solids and sediment), chemical (hydrolysis, photolysis) and biological removal mechanisms (e.g., microbial degradation, uptake) in addition to flow and other water characteristics (Baughman and Lassiter, 1978). Two important chemical measurements, $\mathrm{pK}_{\mathrm{a}}$ and $\log D_{\mathrm{OW}}$ (the $\mathrm{pH}$-dependent $n$-octanol-water distribution ratio), can provide strong evidence of whether compounds will be in an ionized state, their hydrophobicity, and can help determine whether they will partition into water, biosolids, sediment and/or biological media (Wells, 2006).

Most WWTPs in the US are operated between $\mathrm{pH} 7$ and $\mathrm{pH} 8$. Therefore, this range will be considered in calculating $\log D_{\mathrm{OW}}$ (Wells, 2006; Supplemental Table 1). For example, the $\log D_{\text {ow }}$ of two of the ECs measured in this study, azithromycin (an antibiotic) and methamphetamine (an illicit drug), are -0.06 and $1.59 \mathrm{log}$ $D_{\mathrm{OW}}$ at $\mathrm{pH} 7$, respectively, and -0.72 and $-0.11 \log D_{\mathrm{OW}}$ at $\mathrm{pH} 8$, respectively (values calculated using ACD Labs Phys/Chem History program) (Supplemental Table 1 ). At a $\log D_{\text {ow }}$ of -1 , the $D_{\text {ow }}$ ratio is $0.1 / 1$ equivalent to $1 \times 10^{-1}$; at a $\log D_{\text {ow }}$ value of 0 , the $D_{\text {ow }}$ ratio is $1 / 1$ equivalent to $1 \times 10^{0}$; and at a $\log D_{\text {ow }}$ value of +1 , the $D_{\text {ow }}$ ratio is $1 / 0.1$ equivalent to $1 \times 10^{1}$. Above a $\log D_{\mathrm{ow}}$ of +1 , the likelihood of predominance of the chemical in the aqueous phase decreases logarithmically, whereas below a $\log D_{\text {ow }}$ of -1 , the likelihood of predominance of the chemical in the aqueous phase increases logarithmically. Therefore, compounds having $\log D_{\text {ow }}$ values in the region between -1 to +1 at a $\mathrm{pH}$ of $7-8$ would be anticipated to be found distributed in both the water phase and organic phase during water treatment and transport. Indeed, both azithromycin and methamphetamine have been detected in the water column and in biosolids (Banta-Green et al., 2009; Jones-Lepp et al., 2011; Jones-Lepp and Stevens, 2007; Kim and Aga, 2007; Le-Minh et al., 2010; Loganathan et al., 2009).

Table 2

Concentrations of analytes detected from POCIS (only samples with at least one detection are shown).

\begin{tabular}{|c|c|c|c|c|c|c|c|}
\hline \multirow[b]{2}{*}{ Site names } & \multirow[b]{2}{*}{ Date deployed } & \multicolumn{6}{|l|}{$\begin{array}{l}\text { Analytes } \\
\mathrm{ng} / \mathrm{L}\end{array}$} \\
\hline & & Azithromycin & Methamphetamine & MDMA & Clindamycin & Pseudoephedrine & Hydrocodone \\
\hline \multicolumn{8}{|l|}{2008} \\
\hline Las Vegas Wash & 09/08/08 & - & 14 & 0.8 & 9.5 & 12 & NA \\
\hline \multicolumn{8}{|l|}{2008} \\
\hline Willow Beach & $12 / 02 / 08$ & - & - & - & - & - & 22 \\
\hline \multicolumn{8}{|l|}{2009} \\
\hline Las Vegas Wash & 06/21/09 & 0.5 & 6.5 & - & 26 & - & 71 \\
\hline Northern International Boundary & 07/09/09 & - & 2.4 & - & - & - & - \\
\hline
\end{tabular}

“-” = not detected. NA = compound was not analyzed. 
This interaction between aqueous and solid phases can also be understood by looking at the $\mathrm{pK}_{\mathrm{a}} \mathrm{s}$, as well as the $\log D_{\mathrm{ow}} \mathrm{s}$. For example, hydrocodone has a $\mathrm{pK}_{\mathrm{a}}$ of 8.52 (calculated using ACD/PhysChem software), indicating that it would be $50 \%$ charged and $50 \%$ neutral at $\mathrm{pH}$ 8.52. Because hydrocodone is a base at $\mathrm{pH} 8$ (below the $\mathrm{pK}_{\mathrm{a}}$ ) it is even greater than $50 \%$ charged, therefore, at $\mathrm{pH} 8$ where it is more than $50 \%$ charged, it can be concluded from the $\log D_{\text {ow }}$ of 1.94 , that even the ionized form of hydrocodone is still rather hydrophobic. However, because hydrocodone was detected in water samples, hydrocodone can be considered as an example of a base being a hydrophobic ionogenic organic compound (HIOC) (Wells, 2006). In terms of the transport of hydrocodone through a water treatment plant (which operates at about $\mathrm{pH} 7-8$ in the US), it could be predicted that hydrocodone will be detected in both the water and the sludge phases. Most of the compounds in this study have $\log D_{\mathrm{OW}}$ values that are $<1$, indicating that they would be detected in the water column after release from WWTPs. Those compounds that have $\log D_{\text {ow }}$ values that are $>1$, like the antibiotics and hydrocodone, were still detected in the water column, consistent with the $\mathrm{pK}_{\mathrm{a}}$ data. Empirical data from this study supports the $\log D_{\mathrm{ow}}$ calculations, in that all of the compounds in this study were detected at some level in the effluents from various WWTPs and non-WWTP sources in the CRB.

Of course, in complex natural water and wastewater samples, partitioning due to hydrophobicity/lipophilicity is not the only physicalchemical force of attraction operating between molecules. Ion-pair formation and irreversible covalent bonding with organic surfaces in environmental media also occur. However, investigation of pseudo-equilibrium partitioning in these systems is a useful predictor of environmental fate and transport, and $\log D_{\mathrm{ow}}$ (the $\mathrm{pH}$-dependant hydrophobicity) is more appropriate in these instances than $\log K_{\mathrm{OW}}$.

\subsection{Temporal data}

Presented in Fig. 2 is a graph showing the temporal variation of azithromycin, methamphetamine and pseudoephedrine from the Tucson WWTP. There is a significant increase in azithromycin starting in late spring (April 2008) and diminishing concentrations by early summer (June 2008). However, azithromycin never entirely goes away due to its constant use through high prescription rates in the US, (DrugTopics.com, 2010); thereby, labeling it as a pseudopersistent (Daughton, 2002) compound in the effluent waste stream. For methamphetamine, there is an increase in the summer months, but lower concentrations in the winter and spring. There is a notable increase in pseudoephedrine as late spring arrives, and one can assume that more allergies and hay fever are present, therefore increasing the use of pseudoephedrine.

Other researchers have used data from WWTP effluents to look at temporal, and spatial variations of different classes of drugs. For example, Backe et al. (2011) report on temporal trends of androgen loading from a relatively small WWTP in the US Pacific Northwest. van Nuijs et al. (2009) reported on both spatial and temporal variations of cocaine and its metabolite, benzoylecgonine, in water samples and WWTP effluents from Belgium. Using principal component analysis (PCA) Terzic et al. (2010) were able to evaluate, over an 8 month period, the temporal variations of several psychoactive substances and their metabolites from a major WWTP in Zagreb (Croatia). Feitosa-Felizzola and Chiron also show temporal changes, between winter and spring, in antibiotic usage along the Arc River, in Southern France (Feitosa-Felizzola and Chiron, 2009).

\subsection{Estrogenic assays}

Extracts from the deployed POCISs were screened for the presence of estrogenic chemicals using the YES assay. Six of the eight sites were sampled in both 2008 and 2009. At each of these sites, the measured estrogenicity was greater in 2008 than in 2009 (Table 3). Extracts from the 2008 deployment in the Las Vegas Wash showed the second highest estrogenicity, which was not unexpected as this site is heavily influenced by treated wastewater. However, the presence of high levels of toxic chemicals in the 2009 POCIS extracts masked estrogenicity measurements from the Las Vegas Wash. In these extracts, there was an observation of yeast cell death at the highest concentrations of the extract during the YES procedure. The observation of yeast cell death was indicative of toxic chemicals present in the extract. The other site that provided the highest level of response for estrogenicity (2.4) was from one of the Lake Havasu sites $\left(114^{\circ} 19^{\prime}\right.$ $29^{\prime \prime} \mathrm{W}$ and $34^{\circ} 26^{\prime} 55^{\prime \prime} \mathrm{N}$ ). It is unknown as to why the response was so great from the 2008 extracts from that site, as the POCIS deployment site was in a remote cove along the Colorado River located approximately $3 \mathrm{~km}$ ( 2 miles) downstream from the nearest WWTP effluents. Overall, the estrogenicity measured at most sites was low; however, of those that measured a response, the measured levels may be approaching biologically-relevant concentrations.

\section{Conclusions}

Increasing demands on scarce water resources in the southwestern part of the United States have forced water authorities to look for alternative water sources. One alternative is the use of treated municipal wastewater. This has led to a growing number of water management entities to utilize wastewater effluent to stretch their water consumptive needs. Effluent has been utilized directly from wastewater treatment plants primarily for nonresidential irrigation and for recharging depleted groundwater resources via percolation ponds or injection wells. Some water authorities treat the wastewater using advanced dual-membrane (microfiltration and reverse osmosis) and ultraviolet technologies and then inject the treated used water into ground water aquifers, and pump it out later for further treatment and use as drinking water, or for non-potable water reuse, e.g., use on golf courses, municipal green spaces, etc. This type of reuse has been practiced in several parts of the United States for more than 30 years. For example, in the Orange County Water District, Southern California, high quality water reclaimed from treated used water has been injected into ground water since 1976. Other water providers in the Southwest, such as the Phoenix Active Management Area of central Arizona, also recharge their treated wastewater effluent into groundwater reservoirs. Other entities such as the City of Scottsdale, AZ, which is recognized as one of the largest municipal facilities in the world, treats raw wastewater to potable quality for aquifer recharge. The City of Lake Havasu also uses a new stateof-the-art advanced wastewater treatment facility for groundwater recharge. The goal of the City of Lake Havasu is to take the ultratreated wastewater and inject it into a specially created underground berm, and after further treatment, to eventually use it as source water for the City of Lake Havasu.

Knowing that WWTPs can be a significant source of ECs in the Colorado River and its tributaries will hopefully lead water management

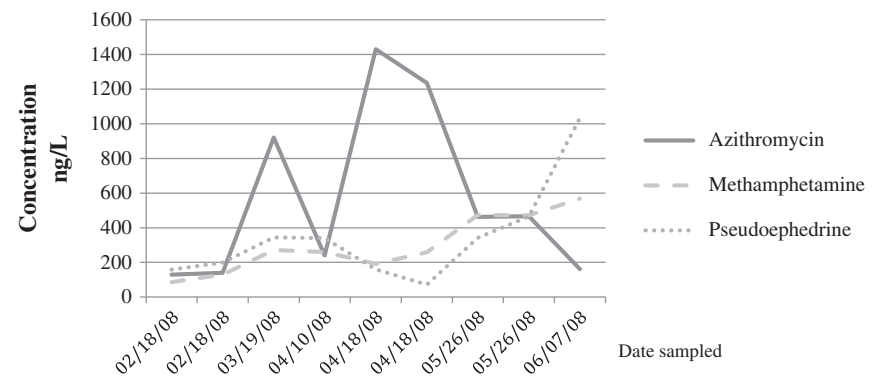

Fig. 2. Temporal trends of azithromycin, methamphetamine, and pseudoephedrine from Tucson WWTP. 
Table 3

Relative estrogenic potential of chemicals sampled by the polar organic chemical integrative samplers (POCIS) measured by the yeast estrogen screen (YES).

\begin{tabular}{|c|c|c|c|}
\hline & $\begin{array}{l}2008 \text { (June-September) } \\
\text { ng E2/L } \text { L }^{\mathrm{a}}\end{array}$ & $\begin{array}{l}2008 \text { (December) } \\
\text { ng E2/L }\end{array}$ & $\begin{array}{l}2009 \text { (June-July) } \\
\text { ng E2/L }\end{array}$ \\
\hline Lake Havasu & 2.4 & Not sampled ${ }^{\mathrm{b}}$ & Trace $^{c}$ \\
\hline Diamond Creek & Not sampled & 0.73 & $-{ }^{d}$ \\
\hline Willow Beach & 0.24 & 0.66 & - \\
\hline Las Vegas Wash & 1.9 & Not sampled & $0.26^{\mathrm{e}}$ \\
\hline Lee's Ferry & 0.04 & Not sampled & - \\
\hline $\begin{array}{l}\text { Northern } \\
\text { International } \\
\text { Boundary }\end{array}$ & Not sampled & Not sampled & 1.2 \\
\hline $\begin{array}{l}\text { Imperial } \\
\text { Diversion Dam }\end{array}$ & 0.43 & Not sampled & 0.04 \\
\hline Cibola & Not sampled & Not sampled & 0.05 \\
\hline
\end{tabular}

a Estimated estradiol equivalents reported in units of nanograms of $17 \beta$-estradiol per liter back-calculated from ng E2/POCIS data.

b Not sampled - POCIS were not deployed during this time period.

c Estrogenicity was observed above the $99 \%$ confidence interval of the blanks, but was below a measurable level.

d “-" = not detected.

e Estrogenicity was masked by toxicity in the extract.

authorities to a better understanding of ECs in their source waters, that are used for drinking water. For example, some compounds, like azithromycin, can be thought of as pseudopersistent (Daughton, 2002; Daughton and Ternes, 1999) in that they are always present in the waste streams due to their widespread use by humans. Other compounds with higher water solubilities, such as methamphetamine, MDMA and pseudoephedrine, can travel for several kilometers downstream from the WWTPs, or are introduced during recreational activities on the water resource (e.g., lakes, streams, reservoirs). The temporal variations (Fig. 2) in the release of different ECs at different times of the year can also lead to an improved understanding of wastewater treatment technologies that perhaps could be tailored more specifically towards certain classes of compounds.

The cumulative impact to human health and aquatic ecosystems from the release of multiple ECs (e.g., antibiotics, steroids, hormones, illicit drugs) into the aquatic environment is uncertain. Most levels of ECs detected in the environment are below the toxicity threshold for an acute effect. However, due to the pseudopersistence of many of the ECs it may be possible to elicit an effect from chronic exposure. For example, Brain et al. (2004) showed that certain classes of antibiotics and other pharmaceuticals elicited a phytotoxic response in aquatic macrophytes. Kümmerer (2010) points out that targeted ecotoxicological studies of ECs are lacking, and that chronic effects often do not have visible results and can remain hidden for a much longer time. Chronic exposure, as well as acute exposure, to ECs will likely be of increasing importance in a water commodity-based future where water reuse, and recycling, will play an ever-increasing role, along with the probability of increasing ECs into source water supplies.

\section{Acknowledgments}

We would like to thank Dr. Martha Wells for her insightful discussions on $\log D_{\text {ow }}$ and how it pertains to environmental occurrence. We would also like to thank Dr. Don Betowski for his review of the supplemental material and review of the LOD calculations.

Notice: The United States Environmental Protection Agency through its Office of Research and Development funded and managed the research described here. It has been subjected to the Agency's administrative review and approved for publication. Mention of trade names or commercial products does not constitute endorsement or recommendation for use.

\section{Appendix A. Supplementary data}

Supplementary data to this article can be found online at doi:10. 1016/j.scitotenv.2012.04.053.

\section{References}

Alvarez D, Cranor W, Perkins S, Clark R, Smith S. Chemical and toxicological assessment of organic contaminants in surface water using passive samplers. J Environ Qual 2008;37:1024-33.

Alvarez D, Petty J, Huckins J, Jones-Lepp T, Getting D, Goddard J, et al. Development of a passive, in situ, integrative sampler for hydrophilic organic contaminants in aquatic environments. Environ Toxicol Chem 2004;23:1640-8.

Backe W, Ort C, Brewer A, Field J. Analysis of androgenic steroids in environmental waters by large-volume injection liquid chromatography tandem mass spectrometry. Anal Chem 2011;83:2622-30.

Banta-Green CJ, Field JA, Chiaia AC, Sudakin DL, Power L, De Montigny L. The spatial epidemiology of cocaine, methamphetamine and 3,4-methylenedioxymethamphetamine (MDMA) use: a demonstration using a population measure of community drug load derived from municipal wastewater. Addiction 2009;104:1874-80.

Bartelt-Hunt SL, Snow DD, Damon T, Shockley J, Hoagland K. The occurrence of illicit and therapeutic pharmaceuticals in wastewater effluent and surface waters in $\mathrm{Ne}$ braska. Environ Pollut 2009;157:786-91.

Baughman G, Lassiter R. Prediction of environmental pollutant concentration, Vol. 657. ASTM; 1978.

Blasco C, Pico Y. Prospects for combining chemical and biological methods for integrated environmental assessment. Trends Anal Chem 2009;28:745-57.

Boles TH, Wells MJM. Analysis of amphetamine and methamphetamine as emerging pollutants in wastewater and wastewater-impacted streams. J Chromatogr A 2010;1217:2561-8.

Borci T. EPA Region 1 enforcement actions illicit sewage connections; personal communication with TJones-Lepp, 2012.

Brain RA, Johnson DJ, Richards SM, Hanson M, Sanderson H, Lam M, et al. Microcosm evaluation of the effects of an eight pharmaceutical mixture to the aquatic macrophytes Lemna gibba and Myriophyllum sibiricum. Aquat Toxicol 2004:70:23-40.

Castiglioni S, Pomati F, Miller K, Burns BP, Zuccato E, Calamari D, et al. Novel homologs of the multiple resistance regulator marA in antibiotic-contaminated environments. Water Res 2008:42:4271-80.

Chiaia AC, Banta-Green C, Field J. Eliminating solid phase extraction with large-volume injection LC/MS/MS: analysis of illicit and legal drugs and human urine indicators in US wastewaters. Environ Sci Technol 2008;42:8841-8.

Daughton C. Environmental stewardship and drugs as pollutants. Lancet 2002;360: 1035-6.

Daughton C, Ternes T. Pharmaceuticals and personal care products in the environment: agents of subtle change? Environ Health Perspect 1999;107:907-38.

DrugTopics.com. Top 200 generic drugs by total prescriptions. Drug Topics; 2010.

Feitosa-Felizzola J, Chiron S. Occurrence and distribution of selected antibiotics in a small Mediterranean stream (Arc River, Southern France). J Hydrol 2009;364:50-7.

Felmingham D, Canton R, Jenkins SG. Regional trends in $\beta$-lactam, macrolide, fluoroquinolone and telithromycin resistance among Streptococcus pneumoniae isolates 2001-2004. J Infect 2007;55:111-8.

Gerrity D, Trenholm RA, Snyder SA. Temporal variability of pharmaceuticals and illicit drugs in wastewater and the effects of a major sporting event. Water Res 2011;45: 5399-411.

Gros M, Petrović M, Baceló D. Wastewater treatment plants as a pathway for aquatic contamination by pharmaceuticals in the Ebro River Basin (Northeast Spain). Environ Toxicol Chem 2007;26:1553-62.

Jones-Lepp T, Alvarez D, Loganathan B. On the frontier: analytical chemistry and the occurrence of illicit drugs into surface waters in the United States. John Wiley \& Sons, Inc; 2011

Jones-Lepp TL. Chemical markers of human waste contamination: analysis of urobilin and pharmaceuticals in source waters. J Environ Monit 2006;8:472-8.

Jones-Lepp TL, Alvarez DA, Petty JD, Huckins JN. Polar organic chemical integrative sampling and liquid chromatography-electrospray/ion-trap mass spectrometry for assessing selected prescription and illicit drugs in treated sewage effluents. Arch Environ Contam Toxicol 2004:47:427-39.

Jones-Lepp TL, Stevens R. Pharmaceuticals and personal care products in biosolids/sewage sludge: the interface between analytical chemistry and regulation. Anal Bioanal Chem 2007;387:1173-83.

Kemper $\mathrm{N}$. Veterinary antibiotics in the aquatic and terrestrial environment. Ecol Indic 2008;8:1-13.

Kim S, Aga DS. Potential ecological and human health impacts of antibiotics and antibiotic-resistant bacteria from wastewater treatment plants. J Toxicol Environ Health B 2007:10:559-73.

Knapp CW, Dolfing J, Ehlert PA, Graham DW. Evidence of increasing antibiotic resistance gene abundances in archived soils since 1940. Environ Sci Technol 2010;44:580-7.

Kümmerer K. Pharmaceuticals in the environment. Annu Rev Environ Resour 2010;35: 57-75.

Le-Minh N, Khan SJ, Drewes JE, Stuetz RM. Fate of antibiotics during municipal water recycling treatment processes. Water Res 2010;44:4295-323.

Lin AY-C, Yu T-H, Lin C-F. Pharmaceutical contamination in residential, industrial, and agricultural waste streams: risk to aqueous environments in Taiwan. Chemosphere 2008;74:131-41. 
Loganathan B, Phillips M, Mowery H, Jones-Lepp TL. Contamination profiles and mass loadings of select macrolide antibiotics and illicit drugs from a small urban wastewater treatment plant. Chemosphere 2009;75:70-7.

Managaki S, Kim W, Furumai H, Takada $\mathrm{H}$. The difference of diurnal behavior of pharmaceuticals and gross organic pollutants in combined sewer system. 11th International Conference on Urban Drainage, Edinburgh, Scotland, UK; 2008. p. 7.

Merlin C, Bonot S, Courtois S, Block J-C. Persistence and dissemination of the multipleantibiotic-resistance plasmid pB10 in the microbial communities of wastewater sludge microcosms. Water Res 2011;45:2897-905.

Munir M, Wong K, Xagoraraki I. Release of antibiotic resistant bacteria and genes in the effluent and biosolids of five wastewater utilities in Michigan. Water Res 2011;45: 681-93.

Murata A, Takada H, Mutoh K, Hosoda H, Harada A, Nakada N. Nationwide monitoring of selected antibiotics: distribution and sources of sulfonamides, trimethoprim, and macrolides in Japanese rivers. Sci Total Environ 2011;409:5305-12.

Ort C, Schaffner C, Giger W, Gujer W. Modeling stochastic load variations in sewer systems. Water Sci Technol 2005;52:113-22.

Postigo C, Lopez de Alda M, Barceló D. Fully automated determination in the low nanogram per liter level of different classes of drugs of abuse in sewage water by online solid-phase extraction-liquid chromatography-electrospray-tandem mass spectrometry. Anal Chem 2008;80:3123-34.

Rosenblatt-Farrell N. The landscape of antibiotic resistance. Environ Health Perspect 2009;117:A244-50.
Schwartz T, Kohnen W, Jansen B, Obst U. Detection of antibiotic-resistant bacteria and their resistance genes in wastewater, surface water, and drinking water biofilms. FEMS Microbiol Ecol 2003;43:325-35.

Segura PA, Francois M, Gagnon C, Suave S. Review of the occurrence of anti-infectives in contaminated wastewaters and natural and drinking waters. Environ Health Perspect 2009;117:675-84

Seveno NA, Kallifidas D, Smalla K, van Elsas JD, Collard J-M, Karagouni AD, et al. Occurrence and reservoirs of antibiotic resistance genes in the environment. Rev Med Microbiol 2002;13:15-27.

Terzic S, Senta I, Ahel M. Illicit drugs in wastewater of the city of Zagreb (Croatia) estimation of drug abuse in a transition country. Environ Pollut 2010;158: 2686-93.

van Nuijs A, Pecceu B, Theunis L, Dubois N, Charlier C, Jorens P, et al. Spatial and temporal variations in the occurrence of cocaine and benzoylecgonine in waste- and surface water from Belgium and removal during wastewater treatment. Water Res 2009;43:1341-9.

Wells M. Log $D_{\text {ow: }}$ key to understanding and regulating wastewater-derived contaminants. Environ Chem 2006;3:439-49.

Young RA. Determining the economic value of water: concepts and methods. Washington, DC: Resources for the Future; 2005 